\section{Способ выращивания усталостных трещин в ударных образцах}

\author{
О. В. Казачков ${ }^{1}$ \\ Петрозаводский государственный университет
}

Разработан способ и установка для выращивания усталостньх трещин в ударньх образцах. Проведены механические испытания на ударный изгиб. Показана сущность и эффективность данного способа выращивания трещин.

Ключевые слова: способ, установка, вязкость разруиения, ударная вязкость, усталостные трещины, ударный изгиб, механические испытания.

Проблема повышения качества и долговечности выпускаемой автотракторной техники неразрывно связана с изысканием и разработкой качественных материалов и методов оценки их свойств. Наиболее перспективна оценка сталей по вязкости разрушения.

Одним из свойств стали, характеризующих ее вязкость разрушения, является работа на распространение трещин $\left(K C_{P}\right)$, определяемая при испытаниях на ударный изгиб образцов с надрезом. Нередки случаи, когда сталь, обладающая высокой ударной вязкостью KCU, KCV, имеет низкую работу на распространение трещин, а тем самым и низкую работоспособность в условиях эксплуатации. Определение работы на распространение трещин $K C_{P}$, чаще всего производится методами Дроздовского-Фридмана и Гуляева $[1,2]$. Метод Дроздовского-Фридмана основан на создании в ударном образце предварительной усталостной трещины. Недостатком его является то, что для выращивания трещины применяют специальные вибраторы, которыми располагают далеко не все предприятия. В связи с этим разработан способ выращивания трещины в ударных образцах с помощью несложного устройства [3]. Испытания и отработка способа производились на образцах с U- и Vобразным конщентратором сечением $8 \times 10$ мм и глубиной концентратора 2 мм на маятниковом копре с предельной энергией 300 Дж.

Сущность предложенного способа заключается в том, что ударный образец с V-образным концентратором подвергают круговому изгибу с жесткой фиксацией стрелы прогиба на конще образца. Задание жесткой фиксации стрелы прогиба при циклическом нагружении в условиях изгиба с вращением позволяет выращивать усталостные трещины нужной глубины.

Данный способ осуществляется при помощи приспособления, состоящего из кругльх обойм с прямоугольными прорезями и нагрузочного устройства

${ }^{1}$ Автор - дочент кафедры технологии металлов и ремонта

(c) О. В. Казачков, 1999 (рис. 1). На одну из обойм жестко насажен шарикоподшипник.

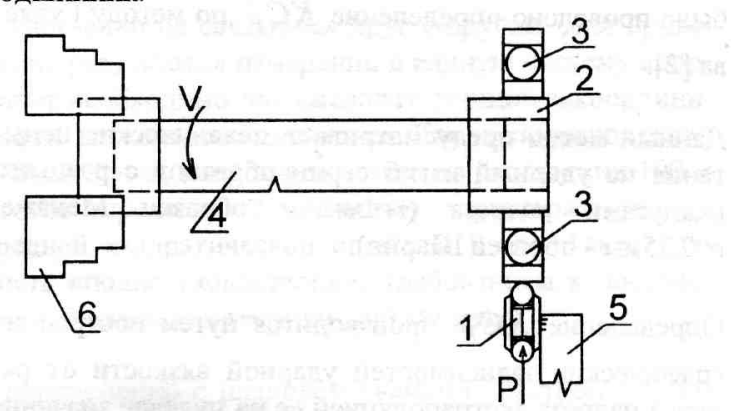

Рис. 1. Приспособление для выращивания усталостных трещин на ударных образцах:

1 - нагрузочное устройство; 2 - обойма; 3 - шарикоподшипник; 4 - образец; 5 - резцедержатель; 6 - патрон токарного образца

Для нанесения трещины используется токарный станок. В этом случае образец зажимается в патрон, а нагрузочное устройство закрепляется в суппорте резцедержателя. Усилие нагрузки контролируется по показаниям электротензометрического динамометра. Установка образца по отношению к нагрузочному устройству позволяет перемещать ролик перпендикулярно к оси образца с погрешностью не более $2^{0,}$, а также плавно изменять прогиб образца и подлерживать его постоянным с погрешностыю не более $5 \%$ в процессе всего испытания. Контроль за ростом трещин проводился визуальньм путем с применением спиртосодержащей жидкости, а также по показаниям электротензометрического динамометра, вследствие изменения изгибной жесткости образца, происходящей в процессе роста трещины.

Полученный таким образом образец соответствовал требованиям, предъявляемьм ГОСТ 9454-78. Трещина имела среднюю глубину $1 \ldots 1,5$ мм. Ее фактическая глубина определялась после разрушения образца с помощью измерительного микроскопа. Внешний вид изломов образцов показан на рис. 2.

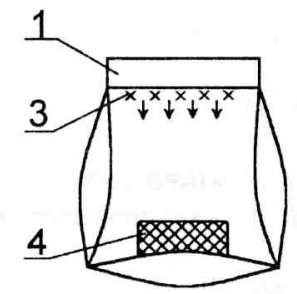

a)

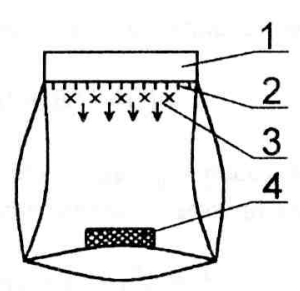

б)
Рис. 2. Внешний вид изломов ударньх образцов:

а) обычный образец;

б) с предварительной трещиной:

1 - конщентратор; 2 - зона усталостной трещины;

3 - зона распространения трещины; 4 - зона долома 
Для анализа полученньх результатов одновременно было проведено определение $K C_{P}$ по методу Гуляева [2].

Данный метод предусматривает механические испытания на ударный изгиб серии образцов с разньми радиусами надреза ( $\mathrm{r}=1$ мм - образец Менаже; $\mathrm{r}=0,25 \mathrm{мм}$ - образец Шарпи).

Определение $K C_{P}$ производится путем построения графических зависимостей ударной вязкости от радиуса надреза экстраполяцией ее на нулевое значение радиуса (рис. 3).

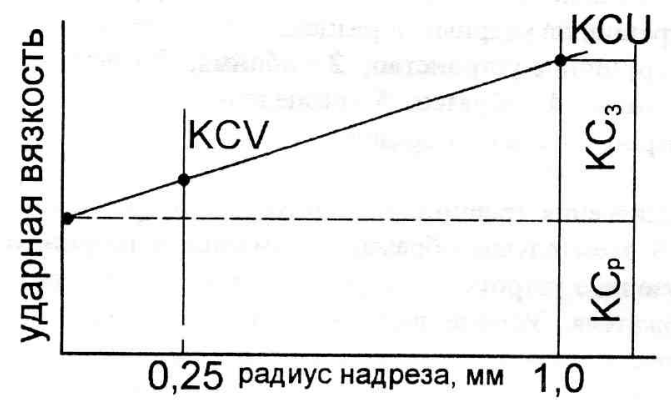

Рис. 3. Определение $K C_{P}$ методом А. П. Гуляева

Результаты механических испьтаний на ударный изгиб приведены в таблице.

\section{Результаты испытаний стали $40 \mathrm{X}$ на ударный изгиб}

\begin{tabular}{|c|c|c|c|}
\hline & \multicolumn{3}{|c|}{ По методу Гуляева } \\
\hline \multirow{2}{*}{ 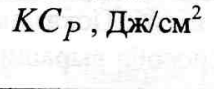 } & KCII & $K C V$ & $K C$ \\
\hline & \multicolumn{3}{|c|}{ 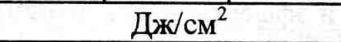 } \\
\hline 36 & 120 & 56 & 34,7 \\
\hline
\end{tabular}

Анализ полученньх результатов показывает, что предложенная методика позволяет получать достоверные результаты, обладающие достаточной сходимостью с результатами, полученными по методу Гуляева.

\section{ЛИТЕРАТУРА}

1. Дроздовский Б. А., Фридман Я. Б. Влияние трещин на механические свойства конструкционньх сталей. М.: Металлургиздат, 1960. 260 с.

2. Гуляев А. П. Металловедение. М.: Металлургия. 1986. $544 \mathrm{c}$.

3. А. с. 1610393 СССР, МКИ G O1 N3/33 Устройство для нанесения усталостных трещин / Казачков О. В.; Опубл. 20.10. 90. Бюл. №44. 200 с.

4. Гуляев А. П. Ударная вязкость и хладноломкость конструкционной стали. М.: Машиностроение, $1969.69 \mathrm{c}$. 